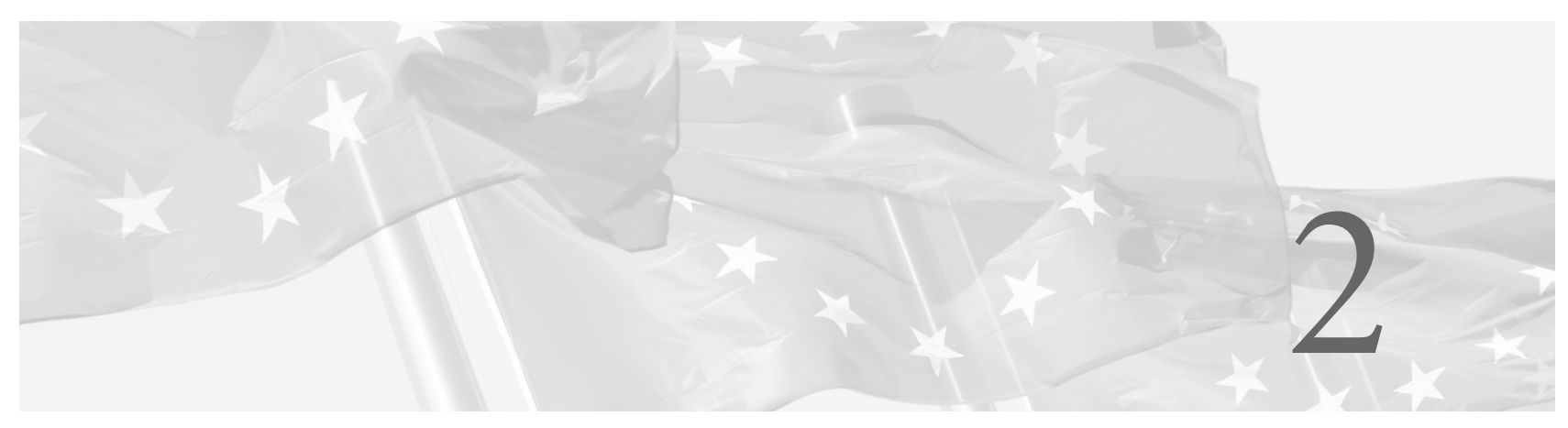

\title{
Rational Choice and EU Politics
}

\author{
MARK A. POLLACK
}

\section{INTRODUCTION}

Rational choice approaches to politics did not originate in the study of the European Union (EU), nor is 'rational choice' as such a theory of European integration or of EU politics. ${ }^{1}$ Rational choice, like constructivism, should be understood as a broad approach to social theory, capable of generating an array of specific theories and testable hypotheses about a range of human behaviors. Over the past two decades, rational choice theories have made rapid inroads into the study of EU politics, most notably through the application of rational choice institutionalism to the study of EU decision-making. In this Chapter, I provide a brief introduction to rational choice theory, examine the application of rational choice analyses to EU politics, assess the empirical fruitfulness of such analyses and identify both internal and external challenges to the rational choice study of the EU.

The chapter is organized in five parts. In the first, I briefly summarize rational choice as a 'second-order' theory of human behavior and discuss the development of rational choice institutionalism (RCI), which has been the most influential branch of rational choice in $\mathrm{EU}$ studies. This section also discusses some of the most common criticisms of rational choice as an approach to human behavior, with an emphasis on its purported methodological 'pathologies' and (lack of) empirical fruitfulness, and its alleged inability to theorize about endogenous preference formation or change. The second section briefly considers the range of first-order rational choice theories of European Union politics, starting with traditional integration theories and continuing through liberal intergovernmentalist, RCI and other mid-range theories of EU politics. In the third section, I address empirical applications of rational choice theories, noting the charges of methodological pathologies but also suggesting that rational choice approaches have produced progressive research programs and shed light on concrete empirical cases including the legislative, executive and judicial politics of the EU, as well as on other questions such as public opinion and Europeanization. Rational choice-inspired empirical work on the EU, I argue, has been predominantly progressive, not pathological. The fourth section examines some of the challenges to rational choice theories, including rationalism's 
purported 'ontological blindness' to a range of empirically important issues, including most notably the issues of endogenous preference formation and change. Like Checkel's review of constructivist theory (in this volume), I do not focus primarily on the rationalist-constructivist debate in EU studies, but I do suggest, against several recent analyses, that the rationalist-constructivist debate in EU studies has largely been a useful and pragmatic one, which has forced rationalists to confront difficult issues like endogenous preference formation and sources of change. A brief fifth section concludes.

\section{RATIONAL CHOICE AS A SECOND-ORDER (META-) THEORY}

Rational choice is, in Wendt's terms, a 'secondorder' theory, concerned with ontological and epistemological questions such as 'the nature of human agency and its relationship to social structures, the role of ideas and material forces in social life, the proper form of social explanations and so on'. ${ }^{2}$ By contrast with such broad, second-order social theories, 'firstorder' theories are 'substantive', 'domainspecific' theories about particular social systems such as the family, Congress, the international system or the EU. Such first-order theories are derived from and should be consistent with the broader second-order theories to which they belong, but they go beyond second-order theories in identifying particular social systems as the object of study, in making specific assumptions about those systems and their constituent actors and in making specific causal or interpretive claims about them (Wendt 1999: 6; Snidal 2002: 74-5).

As a second-order theory, the rational choice approach relies on several fundamental assumptions about the nature of individual actors and of the social world that they constitute. At this broadest level, rational choice is 'a methodological approach that explains both individual and collective (social) outcomes in terms of individual goal-seeking under constraints ...' (Snidal 2002: 74, emphasis in original). This formulation, in turn, contains three essential elements: (1) methodological individualism, (2) goal-seeking or utility-maximization and (3) the existence of various institutional or strategic constraints on individual choice.

The first of these elements, methodological individualism, means simply that rational choice analyses treat individuals as the basic units of social analysis. By contrast with 'holist' approaches that treat society as basic and derive individual characteristics from society, rational choice approaches seek to explain both individual and collective behavior as the aggregation of individual choices. Individuals, in this view, act according to preferences that are assumed to be fixed, transitive and exogenously given.

Second, individuals are assumed to act so as maximize their expected utility, subject to constraints. That is to say, individuals with fixed preferences over possible states of the world calculate the expected utility of alternative courses of action and choose the action that is likely to maximize their utility. This 'logic of consequentiality' provides a distinctive approach to human action and stands in contrast to both the 'logic of appropriateness', in which action is guided by the aim of behaving in conformity with accepted social norms, and the 'logic of arguing', where actors engage in truth-seeking deliberation, accepting 'the power of the better argument' rather than calculating the utility of alternative courses of action for themselves (Risse 2000).

Third and finally, individuals choose under constraints. That is to say, individuals do not directly choose their ideal states of the world, but weigh and choose among alternative courses of action within the constraints of their physical and social surroundings, and often on the basis of incomplete information. Rational choice institutionalist analyses, for example, emphasize the institutional constraints on individual behavior, exploring how formal and informal institutions shape and constrain the choices of individual actors, while game theorists emphasize the strategic context of individual choices in settings where each individual's payoff varies with the choices made by others. ${ }^{3}$

Rational choice, at this broad, second-order level of analysis, is not a theory of EU politics or even of politics more generally, but an umbrella 
for a family of first-order theories that marry these basic assumptions to an additional set of substantive assumptions about, inter alia, the nature of the actors, their preferences and the institutional or strategic settings in which they interact. Rational choice approaches can, for example, take individuals, organizations or states as their basic unit of analysis. They can adopt a 'thick' conception of rationality, in which actors are assumed to be narrowly self-interested, or a 'thin' conception, in which rational-actors may be self-interested or altruistic and may seek a variety of goals such as wealth, power or even love (Ferejohn 1991). Rational choice models can also differ in terms of their assumptions about individual preferences, the institutional and strategic situations in which individuals interact and the quality of the information available to actors seeking to maximize their individual utility. Many rational choice theories including an increasing number in EU studies are formulated as formal models, which express theoretical models in mathematic terms. ${ }^{4}$ In many other cases, however, theories with rationalist assumptions are formulated and expressed verbally, with little or no use of formal modeling, i.e. 'soft' rational choice.

Given the very basic second-order assumptions laid out above and the considerable variation within rational choice in terms of substantive assumptions, we should understand rational choice, not as a single theory, but as a family of first-order theories connected by common assumptions and methodology. For this reason, as Wendt (1999) and Checkel (this volume) point out with regard to constructivism, rational choice as a secondorder theory cannot be either supported or falsified by empirical evidence. It is, rather, the first-order or mid-range theories of politics derived from rational choice that do - or do not - provide testable hypotheses and insights into the politics of various political systems, including the European Union.

\section{Rational Choice Institutionalism}

Over the past two decades, perhaps the leading strand of rational choice literature - and certainly the most influential in EU studies has been that of rational choice institutionalism, in which formal and (to a lesser extent) informal institutions have been reintroduced to the rational choice study of American, comparative and international politics. The contemporary RCI literature can be traced to the effort by American political scientists in the 1970s to re-introduce institutional factors, such as the workings of the committee system, into formal models of majority voting in the US Congress. Such scholars number examined in detail the 'agenda-setting' powers of the Congressional committees, specifying the conditions under which agenda-setting committees could influence the outcomes of certain Congressional votes. Congressional scholars also developed principal-agent models of legislative delegation of authority to the executive, to independent regulatory agencies and to courts, analysing the independence of these various 'agents' and the efforts of Congressional 'principals' to control them. More recently, Epstein and O'Halloran (1999) and Huber and Shipan (2003) have pioneered a 'transaction-cost' approach to the design of political institutions, hypothesizing that legislators deliberately and systematically design political institutions to minimize the transaction costs associated with making public policy. Throughout this work, rational choice theorists have studied institutions both as independent variables that channel individual choices into 'institutional equilibria' and as dependent variables or 'equilibrium institutions' chosen or designed by actors to secure mutual gains.

Although originally formulated in the context of American political institutions, these models are applicable across a range of other comparative and international political contexts. In recent years, for example, comparativists have applied RCI concepts to the comparative study of the design of political institutions (Huber and Shipan 2003); the significance of 'veto points' and 'veto players' in public policy-making (Tsebelis 2002); and the delegation of powers to independent agencies and courts (Huber and Shipan 2003). In international relations, the RCI approach has proven a natural fit with the 
pre-existing rationalist research program of neoliberal institutionalism and has informed a number of important works on topics including the rational design of international institutions (Koremenos et al. 2003), the delegation of powers to international organizations (Pollack 2003; Hawkins et al. 2006) and forum-shopping among various IOs (Jupille and Snidal 2005). Not surprisingly, RCI has also proven to be one of the fastest-growing theories of European integration and EU politics, as we shall see presently.

\section{Critiques of Rational Choice Theory}

Despite its rapid gains across a range of fields in political science, rational choice as an approach has been subject to extensive critique in recent years. Snidal (2002: 73), in his review of rational choice approaches to IR, usefully distinguishes between 'internal critiques', which accept the basic approach but debate 'how to do rational choice' in methodological terms, and 'external critiques', which identify alleged weaknesses in the approach as a whole. There are several 'internal' critiques of rational choice, according to Snidal, including an ongoing debate about the virtues and vices of formalization, but the most contentious debate of recent years has been the debate over empirical testing and falsification of rational choice theory launched by Green and Shapiro (1994) in their book, Pathologies of Rational Choice Theory: A Critique of Applications in Political Science. Unlike many critics of rational choice, these authors do not object to the core assumptions of the approach or to the use of formal models, and they applaud the scientific aspirations of most rational choice scholars. Instead, as their subtitle suggests, Green and Shapiro (1994: 33) focus on empirical applications of rational choice models, arguing that empirical work by rational choice theorists is subject to a 'syndrome of fundamental and recurrent [methodological] failings' which call into question the contribution of the rational choice enterprise to the study of politics. Specific weaknesses identified by the authors include the following:
- Rational choice theories are often formulated in abstract and empirically intractable ways, with heavy reliance on unobservable factors and with insufficient attention paid to the difficulties of operationalizing the hypothesized variables.

- Rational choice theorists often engage in post hoc or 'retroductive' theorizing, seeking to develop rational choice models that might plausibly explain a set of known facts or an empirical regularity. At the extreme, Green and Shapiro argue, this can become an exercise in 'curve-fitting', in which assumptions are manipulated to fit the data, but no subsequent effort is made to test the resulting model with respect to data other than those used to generate the model.

- When they move from theory to the empirical world, rational choice theorists often search for confirming evidence of their theory, engaging in 'plausibility probes' or illustrations of the theory and selecting cases that are likely to confirm, rather than falsify, their hypotheses.

- When engaging in empirical tests (or illustrations) of their hypotheses, rational choice scholars frequently ignore alterative accounts and competing explanations for the observed outcomes and/or test their hypotheses against trivial or implausible null hypotheses (for example, the notion that political behavior is entirely random).

- Finally, in the rare instances in which 'no plausible variant of the theory appears to work', rational choice scholars engage in 'arbitrary domain restriction', conceding the inapplicability of rational choice in a given domain and, hence, arbitrarily ignoring the theory-infirming evidence from that domain (Green and Shapiro 1994: 33-46).

Green and Shapiro (1994: 7) survey rational choice applications to American politics, where they believe that much of the most sophisticated work has been done, and they find that, even here, most empirical work is marred by unscientifically chosen samples, poorly conducted tests, and tendentious interpretations of results.

Green and Shapiro's critique has been subject to numerous responses from rational 
choice scholars, who suggest that the authors 'misunderstand the theory, overlook its achievements or adhere to naïve methodological standards' in their indictment of rational choice (Friedman 1996a: 5). ${ }^{5}$ For our purposes in this chapter, however, Green and Shapiro's critique serves as a useful cautionary note: While there is little dispute in EU studies that rational choice has made increasing headway into the field, it remains to be seen whether rational choice models have made a genuine contribution to our empirical understanding of EU politics, or whether empirical applications of rational choice to the EU have been subject to the methodological failings identified by Green and Shapiro.

By contrast with these internal critiques, 'external critiques' have been directed at the rational choice by both constructivists (particularly in IR theory) and psychologists (most often associated with behavioral economics), who argue that rational choice emphasizes certain problems and sets aside other issues by assumption, resulting in 'ontological blind spots' and inaccurate renderings of the empirical world. Rational choice is 'found deficient in explaining who the key actors are, in explaining their interests, explaining the origin of institutions, or explaining how these change' (Snidal 2002: 74). In EU studies, this external critique is most common among the growing number of constructivist scholars who argue that EU institutions shape not only the behavior but also the preferences and identities of individuals and member states in Europe (Sandholtz 1996; Checkel 2005a, b; Lewis 2005). The argument is stated most forcefully by Christiansen et al. (1999: 529), who argue that European integration has had a 'transformative impact' on the interests and identities of individuals, but that this transformation 'will remain largely invisible in approaches that neglect processes of identity formation and/or assume interests to be given exogenously'. Similarly, because of its focus on institutional equilibria, other critics have suggested that rational choice is blind to endogenous change, such as appears to be commonplace within the EU.

Later in this Chapter, I examine how the rational choice study of EU politics has responded to these internal and external critiques. With regard to the internal critiques, I examine the empirical contribution of rational choice analyses to five discrete areas of study in EU politics, asking whether these studies have fallen prey to Green and Shapiro's methodological pathologies. With regard to external critiques, I inquire into the ability of rational choice theories to address the issues of endogenous preference formation and change. First, however, I consider the role of rational choice analysis in the development of theories of European integration and EU politics.

\section{FIRST-ORDER THEORIES OF EUROPEAN INTEGRATION AND EU POLITICS}

How has rational choice, as a second-order theory, influenced and shaped the study of the European Union, including first-order theories of European integration and EU politics? Ideally, at this stage one could review the history of European integration theory, identifying the various theories as rationalist or not rationalist, and weighing the fruitfulness of each of the two categories. Unfortunately, as Jupille (2005: 220) points out, such an endeavor is complicated by the fact that 'scholars are not always explicit about [their] metatheoretical commitments, which makes it hard to identify what is on offer, what is being rejected, and what is at stake'. In the neofunctionalist-intergovernmentalist debates of the 1960s and 1970s, the primary differences between the two bodies of theory were substantive, focusing primarily on the relative importance of various actors (national governments vs supranational and subnational actors) and on the presence or absence of a self-sustaining integration process. The neofunctionalist/intergovernmentalist debate was not primarily about second-order questions, and indeed the basic assumptions of each theory - the relationship between agents and structure, the logic of human behavior, etc. - were often left undefined. Haas's $(1958,2001)$ neofunctionalism, for example, assumed that both the supranational Commission and subnational interest groups were sophisticated actors capable of calculating their respective bureaucratic and economic 
advantage and acting accordingly, and in this sense Haas laid the groundwork for future rationalist theories of integration (Moravcsik 1998). By the same token, however, Haas's (2001) theory also focused on the possible transfer of 'loyalties' from the national to the European level, without specifying clearly the nature of such loyalties, and constructivists have subsequently come to identify their work with this strand of neofunctionalist theory (Risse 2005).

Intergovernmentalist theory, in turn, drew largely from the soft rational choice tradition of realist theory, identifying the EU's member governments implicitly or explicitly as rational actors who were both aware of and capable of forestalling the transfer of authority to supranational institutions in Brussels (Hoffmann 1966). By contrast with later rational choice work, however, early intergovernmentalist works seldom specified a clear set of preferences for member governments, beyond a generic concern for national sovereignty, and they typically neglected to model the strategic interaction between governments and the supranational agents they had created.

In the 1990s, intergovernmentalist theory gained a clearer set of microfoundations with Moravcsik's (1998) 'liberal intergovernmentalism'. In various writings, and particularly in his book, The Choice for Europe, Moravcsik refined intergovernmentalism into an explicitly rationalist theory in which actors were clearly specified, and predictions about outcomes made, at various levels of analysis. Specifically, Moravcsik (1998: 9) nests three complementary middle-range theories within his larger rationalist framework: (1) a liberal model of preference formation, (2) an intergovernmental model of international bargaining and (3) a model of institutional choice (drawn largely from the RCI literature reviewed above) stressing the importance of credible commitments.

As noted earlier, however, the rational choice study of the European Union is most closely associated with rational choice institutionalists who have sought to model both the workings and the choice of EU institutions. Beginning in the late 1980s, authors such as Scharpf, Tsebelis and Garrett sought to model in rational choice terms the selection and above all the workings of EU institutions, including the adoption, execution and adjudication of EU public policies. $^{6}$ Like the broader literature from which these studies drew inspiration, RCI scholars have theorized EU institutions both as dependent variables - as the object of choices by the EU's member governments - and as independent variables that have shaped subsequent policymaking and policy outcomes.

While much of this literature has been applied to the workings of EU institutions, the growing literatures on Europeanization and on EU enlargement have also drawn on rational choice institutionalism to generate hypotheses about the ways in which, and the conditions under which, EU norms and rules are transmitted from Brussels to the domestic politics and polities of the various member states (Schimmelfennig and Sedelmeier 2005a; Börzel and Risse, this volume).

Furthermore, as Ray, Raunio and Richardson make clear in their respective chapters on public opinion, political parties and organized interests (this volume), rational choice theories of politics have also informed the study of the attitudes and the behavior of subnational actors in the EU. The sources of these theoretical approaches have been varied, including Eastonian models in the public opinion literature, spatial models of party competition in the political parties literature and Olsonian collective action models in the study of EU organized interests, and in all three cases rational choice approaches continue to co-exist with alternative approaches. In each case, however, the respective EU literatures have become more theoretically oriented over time and rational choice theories have played a key role in the study of domestic and transnational behavior by individuals, parties and organized interests.

\section{HAVE RATIONAL CHOICE THEORIES BEEN EMPIRICALLY FRUITFUL IN EU STUDIES?}

The growing presence of rational choice theory in EU studies, however, raises an additional set of questions: Has rational choice 
been empirically fruitful, in the sense of generating testable first-order hypotheses about outcomes in EU politics? Have these hypotheses been subjected to careful and systematic testing, free from the 'pathologies' identified by Green and Shapiro? And, if so, have rationalist hypotheses found support in rigorous empirical testing? While a complete response to such questions is beyond the scope of this chapter, the chapters in this volume each of which provides a thorough review of the scholarship undertaken in a particular area of EU studies - provide a useful starting point for at least a preliminary answer. Indeed, a careful reading of the chapters of this book will reveal that rational choice theory now has been applied to virtually every area of EU politics. Nevertheless, it is fair to say that rational choice theory employs a 'positive heuristic' that directs the analyst's attention to particular types of questions, and so the contribution of rational choice has not been uniform across questions or issue-areas (Lakatos 1970: 135).

Reflecting the widespread importation of RCI into EU studies, rational choice applications have made the greatest headway in the study of EU institutions, and in particular in the areas of legislative, executive and judicial politics. In each of these areas, scholars have been able to draw on a series of 'off-the-shelf' theories and models, and previous reviews have focused largely on these areas (see e.g. Jupille and Caporaso 1999; Dowding 2000; Moser et al. 2000; Aspinwall and Schneider 2001; Pollack 2004; Hix 2005; Scully 2005). As noted above, however, rational choice theories are no longer limited to the study of formal EU institutions, but have begun to be applied to other questions, such as the Europeanization of domestic politics and public opinion toward the EU, among others. In this section, I review the empirical applications and tests of rational choice theories in each of these five areas, drawing largely from the excellent reviews of these areas in the chapters of this book. ${ }^{7}$ By and large, as we shall see, the balance sheet in these five areas is positive: while there is some evidence that the positive heuristic of rational choice theories has directed scholars' attention to certain questions to the exclusion of others, and while some work in each of these fields has been characterized by one or another of Green and Shapiro's methodological pathologies, across the five areas rational choice theories have generated specific, testable hypotheses and the resulting empirical work has dramatically improved our understanding of EU politics and largely (although not invariably) supported the rationalist hypotheses in question.

\section{Legislative Politics}

Without doubt the best-developed strand of rational choice theory in EU studies has focused on EU legislative processes. Drawing heavily on theories and spatial models of legislative behavior and organization, students of EU legislative politics have adapted and tested models of legislative politics to understand the process of legislative decision-making in the EU. This literature, as McElroy points out in her chapter (this volume), has focused on three major questions: legislative politics within the European Parliament; the voting power of the various states in the Council of Ministers; and the respective powers of these two bodies in the EU legislative process.

The European Parliament (EP) has been the subject of extensive theoretical modeling and empirical study over the past two decades, with a growing number of scholars studying the legislative organization of the EP and the voting behavior of its members (MEPs), adapting models of legislative politics derived largely from the study of the US Congress. The early studies of the Parliament, in the 1980s and early 1990s, emphasized the striking fact that, in spite of the multinational nature of the Parliament, the best predictor of MEP voting behavior is not nationality but an MEP's 'party group', with the various party groups demonstrating extraordinarily high measures of cohesion in roll-call votes. These MEPs, moreover, were shown to contest elections and cast their votes in a twodimensional 'issue space', including not only the familiar nationalism/supranationalism dimension but also and especially the more traditional, 'domestic' dimension of left-right 
contestation (Hix 2001). Still other studies have focused on the legislative organization of the EP, including not only the party groups but also the Parliament's powerful committees, whose members play an important agenda-setting role in preparing legislation for debate on the floor of Parliament (Kreppel 2001). Perhaps most fundamentally, these scholars have shown that the EP can increasingly be studied as a 'normal parliament' whose members vote predictably and cohesively within a political space dominated by the familiar contestation between parties of the left and right (Hix et al. 2002).

By contrast with this rich EP literature, McElroy notes, the rational choice literature on the Council of Ministers has until very recently focused primarily on the question of memberstate voting power under different decision rules. In this context, a number of scholars have used increasingly elaborate formal models of Council voting to establish the relative voting weights and hence the bargaining power - of various member states under various qualified majority voting (QMV) voting formulae. The use of such voting-power indexes has led to substantial debate among rational choice scholars, with several scholars criticizing the approach for its emphasis on formal voting weight at the expense of national preferences (Albert 2003). Whatever the merit of voting-power indexes, it is worth noting that the study of Council decision-making appears to be an area in which the use of offthe-shelf models has - at least initially - focused researchers' attention onto a relatively narrow set of questions, at the expense of other questions of equally great substantive interest. In recent years, however, a growing number of scholars have begun to examine voting and coalition patterns in the Council, noting the puzzling lack of minimum-winning coalitions, the extensive use of unanimous voting (even where QMV is an option) and the existence of a North-South cleavage within the Council. ${ }^{8}$

Third and finally, a large and ever-growing literature has attempted to model in rational choice terms and to study empirically the interinstitutional relations among the Commission (as agenda setter) and the Council and Parliament, under different legislative procedures. Over the course of the 1980s and the 1990s, the legislative powers of the EP have grown sequentially, from the relatively modest and non-binding 'consultation procedure' through the creation of the 'cooperation' and 'assent' procedures in the 1980s and the creation and reform of a 'co-decision procedure' in the 1990s. This expansion of EP legislative power and the complex nature of the new legislative procedures has fostered the development of a burgeoning literature and led to several vigorous debates among rational choice scholars about the nature and extent of the EP's and the Council's respective influence across the various procedures. The first of these debates concerned the power of the European Parliament under the cooperation procedure. In an influential article, Tsebelis (1994) argued that this provision gave the Parliament 'conditional agenda-setting' power, insofar as the Parliament would now enjoy the ability to make specific proposals that would be easier for the Council to adopt than to amend. Other scholars disputed Tsebelis's model, arguing that the EP's proposed amendments would have no special status without the approval of the Commission, which therefore remained the principal agenda setter. This theoretical debate, in turn, motivated a series of empirical studies which appeared to confirm the basic predictions of Tsebelis's model, namely that the Parliament enjoyed much greater success in influencing the content of legislation under cooperation than under the older consultation procedure (Kreppel 1999).

A second controversy emerged in the literature over the power of Parliament under the co-decision procedure introduced by the Maastricht Treaty (co-decision I) and reformed by the Treaty of Amsterdam (codecision II). In another controversial article, Tsebelis (1997) argued that, contrary to common perceptions of the co-decision procedure as a step forward for the EP, Parliament had actually lost legislative power in the move from cooperation to co-decision I. By contrast, other rational choice scholars disputed Tsebelis's claims, noting that alternative specifications of the model predicted more modest agenda-setting power for the EP under cooperation and/or a stronger position for the EP in 
co-decision. Here again, quantitative and qualitative empirical analyses have provided at least tentative answers to the question of EP influence across the various legislative procedures, with the most extensive study suggesting that the EP has indeed enjoyed greater legislative influence under co-decision I than under cooperation, largely at the expense of the Commission (Tsebelis et al. 2001). In any event, the Treaty of Amsterdam subsequently simplified the co-decision procedure, creating a genuinely bicameral co-decision II procedure.

To some observers, these debates have verged on scholasticism, focusing more on model specification than on the empirical reality of legislative decision-making, and coming around to empirical testing relatively late in the day (Crombez et al. 2000; Garrett et al. 2001). Taken as a whole, however, the debate over the EP's legislative powers, like early work on the internal organization of the Parliament, has both clarified the basic theoretical assumptions that scholars make about the various actors and their preferences and motivated systematic empirical studies that have generated cumulative knowledge about the EU legislative process.

\section{Executive Politics}

The study of EU executive politics, Tallberg points out in his chapter, is not the exclusive preserve of rational choice scholars. Neofunctionalists and intergovernmentalists have been debating the causal role of the executive Commission for decades, and the Commission has been studied as well by sociological institutionalists, by students of political entrepreneurship and by normative democratic theorists. Nevertheless, as Tallberg also points out, RCI and principal-agent analysis have emerged over the past decade as the dominant approach to the study of the Commission and other executive actors such as the European Central Bank and the growing body of EU agencies.

These studies generally address two specific sets of questions. First, they ask why and under what conditions a group of (memberstate) principals might delegate powers to (supranational) agents, such as the Commission, the European Central Bank or the Court of Justice. With regard to this first question, principal-agent accounts of delegation hypothesize that member-state principals, as rational actors, delegate powers to supranational organizations primarily to lower the transaction costs of policymaking, in particular by allowing member governments to commit themselves credibly to international agreements and to benefit from the policy-relevant expertise provided by supranational actors. Utilizing a variety of quantitative and qualitative methods, the empirical work of these scholars has collectively demonstrated that EU member governments do indeed delegate powers to the Commission and other agents largely to reduce the transaction costs of policymaking, in particular through the monitoring of memberstate compliance, the filling-in of 'incomplete contracts' and the speedy and efficient adoption of implementing regulations (Moravcsik 1998; Franchino 2002, 2004, 2007; Pollack 2003). By contrast with these positive results, however, scholars have found little or no support for the hypothesis that member states delegate powers to the Commission to take advantage of its superior expertise (Moravcsik 1998; Pollack 2003).

In addition to the question of delegation, rational choice institutionalists have devoted greater attention to a second question posed by principal-agent models: What if an agent such as the Commission, the Court of Justice, or the ECB - behaves in ways that diverge from the preferences of the principals? The answer to this question in principal-agent analysis lies primarily in the administrative procedures that the principals may establish to define ex ante the scope of agency activities, as well as the oversight procedures that allow for ex post oversight and sanctioning of errant agents. Applied to the EU, principal-agent analysis leads to the hypothesis that agency autonomy is likely to vary across issue-areas and over time, as a function of the preferences of the member governments, the distribution of information between principals and agents, and the decision rules governing the application of sanctions or the adoption of new 
legislation. By and large, empirical studies of executive politics in the EU have supported these hypotheses, pointing in particular to the significance of decision rules as a crucial determinant of executive autonomy (Pollack 1997, 2003; Tallberg 2000, 2003).

In sum, the rational choice, principal-agent approach has indeed, as Tallberg argues, come to dominate the study of the Commission and other executive actors in the past several decades. This principal-agent literature, like other rational choice approaches, can be criticized for its focus on a particular set of (albeit very important) questions about the relationship between principals and agents and for its neglect of other equally important questions such as the internal workings of executive organizations like the Commission. Furthermore, as Hix argues in his contribution to this volume, the traditional PA assumption that the Commission is an outlier with particularly intense preferences for greater integration may be misleading in the post-Maastricht era where the EU has already placed markers in nearly every area of public policy. Nevertheless, principal-agent models have provided a theoretical framework to ask a series of pointed questions about the causes and consequences of delegating executive power to EU actors, and they have directed scholars' attention to factors such as transaction costs, information asymmetries and the operation of formal rules and administrative law, that had been neglected or indeed ignored by earlier studies. Just as importantly, challenges such as Hix's can be accommodated within the rational choice tradition and can generate additional testable hypotheses that promise to advance further our systematic knowledge of executive politics in the EU.

\section{Judicial Politics}

In addition to the lively debate about the nature of EU executive politics, rational choice institutionalists have also engaged in an increasingly sophisticated research program into the nature of EU judicial politics and the role of the European Court of Justice, examined by Conant in this volume. Writing in the early 1990s, for example, Garrett (1992) first drew on principal-agent analysis to argue that the Court, as an agent of the EU's member governments, was bound to follow the wishes of the most powerful member states. These member states, Garrett argued, had established the ECJ as a means to solve problems of incomplete contracting and monitoring compliance with EU obligations, and they rationally accepted ECJ jurisprudence, even when rulings went against them, because of their longer-term interest in the enforcement of EU law. In such a setting, Garrett and Weingast (1993: 189) argued, the ECJ might identify 'constructed focal points' among multiple equilibrium outcomes, but the Court was unlikely to rule against the preferences of powerful EU member states.

Responding to Garrett's work, other scholars argued forcefully that Garrett's model overestimated the control mechanisms available to powerful member states and the ease of sanctioning an activist Court, which has been far more autonomous than Garrett suggests, and that Garrett's empirical work misread the preferences of the member governments and the politics of internal market reform. Such accounts suggest that the Court has been able to pursue the process of legal integration far beyond the collective preferences of the member governments, in part because of the high costs to member states in overruling or failing to comply with ECJ decisions, and in part because the ECJ enjoys powerful allies in the form of national courts, which refer hundreds of cases per year to the ECJ via the 'preliminary reference' procedure (Mattli and Slaughter 1995, 1998; Stone Sweet and Brunell 1998; Stone Sweet and Caporaso 1998; Alter 2001). In this view, best summarized by Stone Sweet and Caporaso (1998: 129), 'the move to supremacy and direct effect must be understood as audacious acts of agency' by the Court. Responding to these critiques, rational choice analyses of the ECJ have become more nuanced over time, acknowledging the limits of member-state control over the Court and testing hypotheses about the conditions under which the ECJ enjoys the greatest autonomy 
from its national masters (Garrett 1995; Garrett et al. 1998; Kilroy 1999; Pollack 2003).

More recently, as Conant points out, the literature on the ECJ and legal integration has increasingly moved from the traditional question of the ECJ's relationship with national governments toward the study of the ECJ's other interlocutors, including most notably the national courts that bring the majority of cases before the ECJ and the individual litigants who use EU law to achieve their aims within national legal systems. Such studies have problematized and sought to explain the complex and ambivalent relationship between the ECJ and national courts, as well as the varying litigation strategies of 'one-shot' litigants and 'repeat players' before the courts (Mattli and Slaughter 1998; Alter 2001; Conant 2002). These and other studies, influenced largely (although not exclusively) by rational choice models, have demonstrated the complexities of ECJ legal integration, the inter-relationships among supranational, national and subnational political and legal actors, and the limits of EU law in national legal contexts.

\section{Europeanization in Member States and Candidate Countries}

In contrast to the previous sections, which focused on the behavior and policies of EU institutions, an increasing number of studies have focused in recent years on the effects of the EU on domestic politics within the EU's old and new member states - the 'Europeanization' literature reviewed in this volume by Börzel and Risse. Perhaps most interestingly for our purposes here, Börzel and Risse (2000, this volume) have suggested that Europeanization could be theorized in terms of two distinct mechanisms, the one derived from rational choice and emphasizing a logic of consequences, the other derived from sociological institutionalism and emphasizing a logic of appropriateness. In the former, rationalist version, 'the misfit between European and domestic processes, policies and institutions provides societal and/or political actors with new opportunities and constraints in the pursuance of their interests. Whether these actors could in turn secure domestic changes is hypothesized to depend on two key factors emphasized in off-the-shelf RC theories: the existence of multiple veto players and facilitating formal institutions providing resources and opportunities to various domestic actors. By contrast, the sociological perspective theorized that European norms and rules might exert an influence through persuasion and socialization, with domestic outcomes being mitigated by factors such as the existence of domestic 'norm entrepreneurs' to mobilize domestic support and a political culture conducive to consensusbuilding and cost-sharing (Börzel and Risse 2000: 2). Rationalism and constructivism meet here, not as colliding meta-theories, but as firstorder theories that predict different mechanisms of Europeanization and different facilitating factors that would explain the variable impact of 'Europe' in different domestic settings.

The explicit derivation and testing of competing rationalist and constructivist hypotheses, moreover, has not been limited to the study of Europeanization in the 'old' member states, but has turned since the late 1990s in a concerted fashion to the impacts of the EU on the candidate and new member countries of southern and eastern Europe. Students of EU enlargement had for some time framed many of their research questions in terms of the rationalist-constructivist debate, including a number of studies that grappled with the EU's decision to enlarge and the substantive terms of enlargement negotiated with the candidate countries (Schimmelfennig and Sedelmeier 2002). Toward the end of the 1990s and into the current decade, many of these scholars turned to studying the effects of the $\mathrm{EU}$ on candidate and new member countries.

In the most extensive such study, Schimmelfennig and Sedelmeier (2005a) led a team of researchers who sought explicitly to test alternative rationalist and constructivist hypotheses about the effect of EU membership on the new member states in central and eastern Europe. Drawing on previous rationalist and constructivist work, Schimmelfennig and Sedelmeier (2005b) derived three distinct models of the mechanisms driving the Europeanization of the candidate/new member countries of 
central and eastern Europe. The first, 'external incentives' model was derived from rational choice models of bargaining, focusing on the asymmetrical bargaining power of the $\mathrm{EU}$ and its applicant states and in particular on EU 'conditionality', namely the EU's insistence that candidate countries apply the acquis communautaire as a prerequisite to membership. Against this rationalist model, the authors put up two competing constructivist or sociological institutionalist accounts $-\mathrm{a}$ 'social learning' model predicated on a 'logic of appropriateness' and focusing on the socialization of state and civil-society actors in the target countries, and a 'lesson-drawing' model in which dissatisfied governments in central and eastern Europe actively seek out and import EU practices, with the Union itself playing an essentially passive role.

Schimmelfennig and Sedelmeier's findings, based on a series of case studies cutting across multiple countries and multiple issue-areas, provide striking support for the external incentives model. While various studies in the larger project found some instances of socialization and/or lesson-drawing in the absence of conditionality, the authors conclude that, on balance, 'the external incentives provided by the EU can largely account for the impact of the EU on candidate countries. Observed variations in rule adoption, moreover, are explained in large part by the independent variables hypothesized in the external incentives model, including most notably a credible membership perspective and clear political conditionality (Schimmelfennig and Sedelmeier 2005c: 210-11). Other recent studies employ varying theoretical frameworks and focus on different aspects of the Europeanization process, but here too the general finding is that explicit and credible political conditionality is the most important source of EU leverage and policy change in the new and candidate countries, with socialization and lesson-drawing having a much weaker and more variable impact (Jacoby 2004; Kelley 2004; Vachudova 2005; Schimmelfennig 2005; Zürn and Checkel 2005).

In sum, the growing literatures on Europeanization and enlargement are striking for two features, both of which augur well for the field. First, scholars have generally adopted a pragmatic, 'tool-kit' approach to rational choice and constructivist theories, deriving distinctive causal mechanisms and scope conditions for Europeanization from each theory and testing them with care and precision. Second, in these studies, external incentives in the form of political conditionality have emerged as the best predictor of policy change in old as well as new member states, and the scope conditions associated with rational choice theory have performed well in explaining variation across both issueareas and countries.

\section{Public Opinion and European Integration}

The scholarly literature on EU public opinion, analysed in this volume by Ray, was relatively late to develop, due in large part to the emphasis by early integration theorists on elite attitudes, with mass opinion frequently depicted as a 'permissive consensus' within which elites could pursue integrative schemes (Haas 1958; Lindberg and Scheingold 1970). In recent decades, however, the EU public-opinion literature has blossomed, driven in part by events (direct elections of the European Parliament, dramatic referenda on European integration in EU member states) and in part by the availability of Eurobarometer polling data.

The EU public opinion literature, as Ray points out, has been largely problem-driven and theoretically eclectic, drawing on rational-choice models alongside socialization, political communications and other theoretical approaches to generate competing hypotheses about the determinants of public support for the EU. This eclectic approach can be traced back to Lindberg and Scheingold's (1970) pioneering work on EU support for European integration, in which an essentially rationalist or 'utilitarian' support (based on calculation of tangible economic benefits from integration) was contrasted with 'affective' support rooted in a more 'diffuse and emotional' response to the European project. This distinction has remained a fundamental feature of the subsequent literature, which continues to derive and competitively test hypotheses from diverse theoretical traditions about the determinants of public support for European integration, $\mathrm{EU}$ institutions and $\mathrm{EU}$ policies. 
The rational-choice approach to EU public opinion, which Ray associates with the study of utilitarian support, has itself been theoretically and methodologically diverse, with various scholars identifying different independent variables as determinants of public support and operationalizing both dependent and independent variables in different ways using various survey questions from Eurobarometer and other data sources. Some utilitarian models, for example, have focused on EU fiscal transfers or on objective economic conditions at the national level as predictors of support, while others have identified the objective socioeconomic characteristics of individuals or else subjective individual evaluations of economic costs and benefits, as the best measures of utilitarian support. There is, in other words, no single 'rational choice theory' of EU public opinion, but a huge variety of first-order theories and hypotheses, each of which has been subjected to empirical testing, typically using quantitative analyses of Eurobarometer survey data. The complex and sometimes inconclusive empirical findings of this literature are summarized by Leonard, who notes that the most robust findings point to the importance of socioeconomic status ('human capital') and subjective economic perceptions as predictors of support for European integration. The impact of such utilitarian factors is not uncontested, with some studies arguing that identity is at least as strong a predictor of public opinion toward the EU as economic interest (Hooghe and Marks 2004), but the central place of rational-choice or utilitarian models in the literature is clear.

Perhaps the most striking feature of the public opinion literature for our purposes is its close approximation of Green and Shapiro's (1994) ideal type of social-scientific research. Unlike some other, more theoretically driven areas of EU research, work on EU public opinion has indeed been problem-driven and theoretically eclectic, with even strongly rationalist scholars like Gabel (1998) testing affective and other sources of support alongside utilitarian hypotheses. Furthermore, while one can question the operationalization of variables or the selection of data in any individual study, the public opinion literature as a whole has steered well clear of Green and Shapiro's methodological pathologies, relying as it has on multivariate statistical testing of competing hypotheses drawn from distinct theoretical approaches.

\section{The Empirical Fruitfulness of Rational Choice Theory}

In sum, rational choice theory appears - at least in the five areas examined here - to have been an empirically fruitful as well as a theoretically innovative approach to the study of EU politics. While some literatures have indeed focused for extended periods on model specification in the absence of hard empirical data, over time each of the above literatures has produced specific, testable hypotheses about the relative power of legislative, executive and judicial actors, about the determinants of public opinion toward the EU and about the effects of the EU on domestic politics in the member and candidate states. Just as importantly, moreover, most of the rational choice literature in EU studies appears to have avoided the pathologies identified by Green and Shapiro. While individual studies might derive formal models in the absence of empirical testing or conduct superficial empirical work designed to support or illustrate rather than test theories, many scholars in each of the literatures reviewed above have identified concrete, measurable dependent and independent variables; collected systematic quantitative and qualitative data to test their hypotheses; reported findings (including negative and puzzling findings) honestly; and revised and derived new theories in light of those findings.

By and large, moreover, the hypotheses generated by the various first-order (or middlerange) rationalist theories have found empirical support: MEPs do respond to institutional incentives in their voting behavior; the Commission does appear to enjoy variable influence according to the factors emphasized by principal-agent analysis; the Court of Justice does enjoy extraordinary (but not boundless) discretion vis-à-vis the member governments; individuals do appear to base their opinions of 
the EU in large part on a calculation of expected utility; and member and candidate countries do appear to respond most consistently to material incentives provided by the EU. While the debates in all these areas remain ongoing, the best rational choice work of the past decade has been empirically as well as theoretically rigorous and fruitful and has advanced our understanding of EU politics from the Brussels institutions to the member governments to individual opinions and behavior.

\section{CHALLENGES FOR RATIONALIST ANALYSIS OF THE EU}

Still, the reader may ask, what do rational choice approaches leave out or ignore in their study of EU politics? In addition to the internal' critique of poor empirical work, rational choice has also been subject to an 'external' critique, which emphasizes its limited domain of application and its 'ontological blindness' to important questions. Indeed, even within the five issues examined above, we noticed a tendency for rational choice approaches to focus, at least initially, on questions that are most amenable to study using off-the-shelf models while paying less attention to other equally important questions. Looking beyond our five selected issues, the external critique from constructivism raises three inter-related issues that I examine, very briefly, in this section. I consider first whether the purported 'great debate' between rationalism and constructivism has been a metatheoretical dialogue of the deaf or a useful controversy and I then go on to consider the ability of rational choice approaches to theorize about endogenous preference formation and endogenous sources of change, respectively.

\section{Rationalism vs Constructivism: A Useful Controversy}

Within both international relations and EU studies, the past decade has witnessed a marked change in the presentation of the field. By the late 1990s, and into the early 2000s, it was commonplace for scholars to depict both IR and EU studies as being characterized by a new 'great debate' between rational choice and constructivism, displacing earlier debates such as that between neofunctionalism and intergovernmentalism (Katzenstein et al. 1998; Christiansen et al. 1999; Moravcsik 1999; Checkel and Moravcsik 2001).

By the start of the current decade, however, a number of scholars noted the drawbacks of engaging in a grand meta-theoretical debate between rationalism and constructivism in both IR theory and EU studies. In an influential essay, Fearon and Wendt (2002) focused on the potential pitfalls of organizing the field of international relations around an ontological or empirical debate between rationalism and constructivism writ large. Such an approach, they argue, 'can encourage scholars to be method-driven rather than problem driven in their research', leading scholars to ignore important questions or answers that do not fit easily into the grand debate (Fearon and Wendt: 52). In place of such a debate, the authors suggest that scholars approach rational choice and constructivist approaches pragmatically, as analytical 'tool-kits' that 'ask somewhat different questions and so bring different aspects of social life into focus' (Fearon and Wendt 2002: 53). The study of international politics may indeed be characterized by the existence of two second-order theories, but scholars' empirical work need not - and indeed should not - be organized purely in terms of a zero-sum battle among competing paradigms. Rather, the authors suggest, scholars can and should engage in problem-driven research, drawing on first-order theories from either or both approaches as appropriate.

Within EU studies, scholars have similarly warned against a metatheoretical dialogue of the deaf, seeking instead to encourage dialogue between the two approaches and focusing debate on first-order questions that can be resolved through careful empirical work. Moravcsik (1999), for example, rejects the call for 'more metatheory', calling instead for theorists to articulate 'distinct falsifiable hypotheses' and to test these hypotheses against competing theories from other approaches. 
Along similar lines, three EU scholars (Jupille et al. 2003) have recently put forward a framework for promoting integration of - or at least a fruitful dialogue between - rationalist and constructivist approaches to international relations. Rationalism and constructivism, the authors argue, are not hopelessly incommensurate, but can engage each other through 'four distinct modes of theoretical conversation', namely:

(1) competitive testing, in which competing theories are pitted against each other in explaining a single event or class of events;

(2) a 'domain of application' approach, in which each theory is considered to explain some sub-set of empirical reality;

(3) a 'sequencing' approach, in which one theory might explain a particular step in a sequence of actions (e.g. a constructivist explanation of national preferences) while another theory might best explain subsequent developments (e.g. a rationalist explanation of subsequent bargaining); and

(4) 'incorporation' or 'subsumption', in which one theory claims to subsume the other.

Looking at the substantive empirical work in their special issue, Jupille et al. find that most contributions to the rationalist/constructivist debate utilize competitive testing, while only a small number have adopted the domain of application, sequencing or subsumption approaches. Nevertheless, they see substantial progress in the debate, in which both sides generally accept a common standard of empirical testing as the criterion for useful theorizing about EU politics.

Similarly, the review of empirical applications in EU studies conducted above suggests that the rationalist/constructivist debate has not been a dialogue of the deaf but a 'useful controversy', forcing scholars on both sides to articulate clear assumptions, test their hypotheses against competing explanations and specify alternative causal mechanisms for phenomena like Europeanization. In addition, the rationalistconstructivist debate has pressed rational-choice theorists to address two vital issues that have been at the margins of the approach: endogenous preference formation and change.

\section{Endogenous Preference Formation}

One of the central bones of contention between rationalists and constructivists - both generally and in EU studies - has been the issue of endogenous preference formation. To some extent, this debate has been muddied from the outset by a lack of clarity about the meanings of the terms 'exogenous' and 'endogenous'. For many theorists, exogeneity and endogeneity are characteristics of theories - what they seek to explain and what they leave unexplained. In this view, to say that actor preferences are 'exogenously given' means that the theorist makes no attempt to explain preferences, but simply adopts assumptions about them in order to theorize and make predictions about some other dependent variable or explanandum, such as actor behavior or policy outcomes. By contrast, other theories 'endogenize' actor preferences, in the precise sense of making those preferences the explanandum or dependent variable of the study. Rational choice theorists are typically seen to take the first approach, adopting simplifying assumptions about actor preferences (and hence making them exogenous to the theory, which makes no effort to explain them), whereas constructivists tend to place actors' identities and interests at the center of the analysis and attempt to explain them, frequently with regard to the social contexts that actors inhabit (Fearon and Wendt 2002: 60).

Muddying the waters, however, a slightly different interpretation of exogeneity and endogeneity has arisen in the debate between rational choice institutionalists and constructivists in IR and EU studies. In these institutionalist accounts, a number of constructivist authors have argued that the preferences of various national actors are endogenous to the international institution in question, e.g. that actor preferences are shaped (at least in part) by interaction and socialization at the international level (e.g. Sandholtz 1996; Checkel 2005a, b, Lewis 2005). In contrast, scholars who believe that national preferences are formulated domestically and are unaltered by interaction at the international level are often depicted as claiming that national preferences are exogenous to international institutions. 
This distinction - between preferences being exogenous or endogenous to a theory, as opposed to being exogenous or endogenous to an international institution - matters in assessing the purported 'ontological blindness' of rationalism to this question. If we take the first approach, urged on us by Fearon and Wendt (2002: 60), the question is whether rational choice theories are clearly capable of 'endogenizing' - of seeking to explain - preferences, including the 'national preferences' of states in the international system. If it could be shown that rational choice is truly incapable of theorizing national preferences as an explanandum, then we might argue that the correct relationship between the two approaches may be 'domain of application' or 'sequencing' relationship, in which constructivists focus on explaining preferences and rationalists limit their efforts to modeling interactions among actors with exogenously given preferences.

Such a neat division of labor, however, does not stand up to careful scrutiny. Rational choice theorists have not abandoned the effort to explain actor preferences, particularly in international relations and in EU studies, where national preference formation has been a significant object of study for rationalists as well as constructivists. Within EU studies, for example, Moravcsik's (1998) liberal theory of national preference formation seeks to explain national preferences through the aggregation of individual and producer preferences by national governments and clearly endogenizes national preference formation in this sense. More broadly, rational choice theorists in IR have theorized explicitly and in a variety of ways about the endogenous formation of national preferences, including a range of models that focus on political and economic coalitions, principal-agent relations, audience costs and the effects of regime types and institutional rules on the aggregation of individual preferences at the national level (Snidal 2002: 84-5). By and large, such accounts retain simplifying assumptions about individual preferences, focusing instead on the creation of testable hypotheses about the impact of factors such as economic change and domestic institutions on the aggregation of individual preferences into national preferences. Evolutionary game theorists go even further, seeking to explain individual preference formation through mechanisms of complex learning and selection (Gerber and Jackson 1993; Fearon and Wendt 2002: 65). Clearly, then, rational choice theory is not blind to the question of endogenous preference formation, nor have rationalists been unproductive in formulating and testing first-order theories about it.

Hence, when rationalists in EU studies and international relations are charged with blindness toward endogenous preference formation, it is typically in the second and more narrow sense, i.e. that rationalists are unable to theorize about the purported socializing impact of international/EU institutions on states (or on their representatives). Here, critics of rational choice are on firmer ground: Moravscik's (1998) liberal intergovernmentalism, the most prominent rationalist theory to problematize and explain national preferences, does indeed rule out any socializing impact of international interaction on national preferences, in favor of a purely domestic process of preference formation. Even here, however, rational choice theory is not entirely irrelevant to the study of socialization in EU institutions, and indeed a recent special issue of International Organization usefully formulates and tests three distinct mechanisms of socialization drawn from rational choice theory ('strategic calculation'), sociological institutionalism ('role playing') and Habermasian communicative rationality ('normative suasion') (Checkel 2005a, b). The contributors to the volume take a problem-driven approach, drawing pragmatically from various theoretical approaches to identify different mechanisms of socialization as well as the scope conditions for their operations, and their approach to rationalist theory is open-minded rather than exclusionary. On the one hand, editor Jeffery Checkel suggests that rational choice theories are limited to explaining certain elements of international institutions, including 'behavioral adaptation' (typically as a response to political conditionality and other incentives offered by international institutions) and simple learning (in response to new information provided by international institutions), while true socialization (understood 
as the internalization of norms and a shift from a logic of consequences to a logic of appropriateness) appears to lie outside the core assumptions of the rational choice approach. 'While ... the ontological differences separating rationalism and constructivism are often overstated', he argues, 'the former is nonetheless ill-equipped to theorize those instances in which the basic properties of agents are changing' (Checkel 2005b: 810).

On the other hand, despite these limitations, several of the volume's authors argue that rational choice theory is capable of theorizing important elements of the socialization process and that the empirical findings of the project are in each case subject to a 'double-interpretation', in which empirical outcomes can be construed as consistent with a rational choice as well as a constructivist explanation (Johnston 2005; Zürn and Checkel 2005). Several of the studies in the volume, for example, point to the central importance of material incentives, which emerge as a stronger predictor of sustained compliance than socialization without such incentives, and a general finding of the project is that the researchers did not 'see as much socialization as expected' - findings clearly consistent with even a thick rational choice perspective (Zürn and Checkel 2005: 1068; see also Kelley 2004; Schimmelfennig 2005; Schimmelfennig and Sedelmeier 2005c). Furthermore, they argue, even findings that appear at first glance to be clearly in support of the constructivist approach, such as the emergence of a culture of compromise with the EU's Committee of Permanent Representatives, can be plausibly interpreted in thin-rationalist terms as instances of political delegation, diffuse reciprocity or simple learning (Zürn and Checkel 2005: 1056-1065). For all of these reasons, Zürn and Checkel echo Fearon and Wendt (2002) in advocating a pragmatic approach to the rationalist/constructivist divide, in which overlaps are acknowledged and differences highlighted through a careful dialogue among first- and second-order theories of international politics.

In sum, rational choice theory is certainly capable of theorizing endogenous preference formation, particularly insofar as national preferences are derived from the aggregation of individual preferences through domestic political institutions; and even the study of international socialization can benefit from the articulation of a discrete set of rationalist hypotheses which may fall short of predicting changes in the core preferences of actors, but nevertheless provide compelling explanations for a wide range of related empirical phenomena.

\section{Theorizing Change}

A final weakness of rational choice analysis is its purported inability to theorize change - or more precisely to theorize 'endogenous' change. Here again, we encounter some diversity in the use of the terms exogenous and endogenous. If we take Fearon and Wendt's (2002) definition, invoked above, then a theory that endogenizes change is one that seeks to theorize about and explain the sources of change, whereas a theory that exogenizes change is one that takes the source of change - say, the rise of a new great power, or a change in relative prices on world markets - as an assumption and seeks to examine the effects of that source on an existing equilibrium. The key difference, again, is whether the source of change is taken as an unexplained independent variable (hence, exogenous) or is explained in some way by the theory (endogenous).

Within institutionalist theory, by contrast, the terms endogenous and exogenous have taken on a distinct, if overlapping, meaning. In this view, carefully articulated by Helfer (2006), exogeneity and endogeneity are defined in reference to the institution or organization being studied. In this view, widely shared by institutionalist IR scholars, 'change emanating from IO officials and staff is properly labeled as "endogenous" whereas that change resulting from shifts in state preferences or from alterations to the economic, political or social environment is appropriately described as "exogenous"” (Helfer 2006: 4).

Regardless of which of these definitions we accept, it has become commonplace to suggest that rational choice theories, with their emphasis on stable equilibria from which no actor has an incentive to depart, place a theoretical emphasis on stability rather than on change. Indeed, if the 
definition of an institutional equilibrium is that 'no one has an incentive to deviate from the behavior associated with the institution', then by definition 'any changes in self-enforcing institutions must have an extraneous origin' (Greif and Laitin 2004: 633). Thus, to the extent that rational choice models do address change, such change is typically attributed to exogenous shocks that (temporarily) upset an equilibrium and lead (eventually) to a new equilibrium (Helfer 2006: 4).

Looking specifically to EU studies, it appears that even the best rational choice work shares this tendency to either neglect the issue of change or to attribute change to exogenous shocks. Moravcsik's (1998) The Choice for Europe, for example, problematizes both national preferences and institutional change, but his analysis traces the primary sources of change to exogenous developments in the global economy. Similarly, Carrubba and Volden's (2001) formal model of change in Council voting rules, while also addressing directly the issue of change, attributes those changes to exogenous (unexplained) changes in the number of member states, changes in legislative procedures and changes in policy areas under consideration, each of which can affect the Council's ability to pass legislation and thus provide member states with a rational incentive to consider changes to the Council's voting rules and weights. These works, unlike much rational choice work on the EU, do theorize a process of change, but the sources of change remain exogenous - both to the institutions of the Union and more broadly to the theories being advanced. Given the rapid pace of institutional and policy change in the European Union over the past several decades, this relative inattention to endogenous sources of change - which has long been the bread-and-butter of neofunctionalist theory - seems a surprising lacuna.

As a variant on RCI, historical institutionalism seems a more promising approach to studying change within institutions like the EU. By contrast with rational choice's focus on stable equilibria, historical institutionalism has focused on the effects of institutions over time, and in particular at the ways in which a given set of institutions, once established, can shape or constrain the behavior of the actors who established them. Political institutions and public policies, in this view, are frequently characterized by 'increasing returns', insofar as those institutions and policies create incentives for actors to stick within and not abandon existing institutions, adapting them only incrementally to changing political environments. Insofar as political institutions and public policies are in fact characterized by increasing returns, Pierson $(2000,2004)$ argues, politics will be characterized by certain inter-related phenomena, including: inertia or lock-ins, whereby existing institutions may remain in equilibrium for extended periods despite considerable exogenous change; a critical role for timing and sequencing, in which relatively small and contingent events that occur at critical junctures early in a sequence shape and constrain events that occur later; and pathdependence, whereby early decisions provide rational incentives for actors to perpetuate institutional and policy choices inherited from the past, even when the resulting outcomes are manifestly inefficient. Such theories, while rejecting the equilibrium analysis of much rational-choice work, frequently adopt basic assumptions about actors and institutions that are fully consistent with those of rational choice (North 1990; Pierson 2000, 2004).

Historical institutionalism has been widely applied to the study of the European Union over the past two decades, with a particular emphasis on the path-dependent development of the EU and its policies. Scharpf's (1988) pioneering study of the 'joint-decision trap' in EU policymaking, for example, demonstrated how, under certain conditions of intergovernmentalism, unanimity voting and a status-quo default condition, inefficient $\mathrm{EU}$ policies such as the Common Agricultural Policy could persist and resist reform for extended periods. Similarly, Pierson's (1996) study of EU social policy argued that EU member states had effectively lost control of the policy, thanks to a combination of short time horizons, unintended consequences, change-resistant decision rules and policy adaptation by the beneficiaries of existing EU policies. Generalizing from these studies, we might hypothesize that, ceteris paribus, EU 
institutions and policies will be most resistant to change (a) where their alteration requires a unanimous agreement among member states or the consent of supranational actors like the Commission or the Parliament; and (b) where existing EU policies mobilize cross-national bases of support that raise the cost of reversing or revising them.

By and large, however, these 'first-generation' historical institutionalist works have been more effective in explaining continuity (often in the face of exogenous shocks) than in explaining endogenous change. For this reason, both rational choice and historical institutionalists have devoted increasing attention in recent years to the challenge of theorizing endogenous sources of change as well as stability. Within historical institutionalism, a growing 'second-generation' literature has focused on the central claim that existing institutions and policies may produce not only positive feedbacks that stabilize and reinforce existing equilibria, but also negative feedbacks that create pressures for institutional and policy change. Such feedbacks, it is argued, can produce changes that are gradual in timing but ultimately transformative in effect (Streeck and Thelen 2005; Hall and Thelen 2006; Immergut 2006). Welfare-state programs, for example, may be structured such that the value of benefits erodes over time, and this benefit erosion in turn may lead to a decline in public support for those programs - a clear negative feedback in an issuearea long characterized by the predominance of positive feedback (Immergut 2006).

Within rational choice, the most concerted effort to theorize endogenous sources of institutional change has come from Greif and Laitin (2004), who offer a model of endogenous change that draws upon game-theoretic equilibrium models but introduces a dynamic theory of institutional change. In a standard gametheoretic model, the authors suggest, institutions and their associated behaviors are endogenized (explained), while the environmental context for any given institution (say a given level of technology or the global economy or the global balance of power) is theorized as an exogenous set of 'parameters' that help to define the equilibrium outcome within that institution. In this context, however, it is possible that the workings of an institution can in turn affect the value of its parameters - or what Greif and Laitin call 'quasiparameters' - which in turn may affect the internal equilibrium of the institution, either reinforcing it or undermining it. Self-reinforcing institutions, in this view, are those that change the quasi-parameters of the institution so as to make the institution and the individual behaviors of the actors within it more stable in the face of exogenous changes. Self-undermining institutions, in contrast, are those that change the quasi-parameters such that a previously stable equilibrium is undermined; these institutions, in Greif and Laitin's (2004: 34) terms, 'can cultivate the seeds of their own demise'. Further developing Greif and Laitin's ideas, Büthe (2006) has suggested that the actions of the EU's supranational agents can similarly be theorized as an endogenous source of change, either reinforcing or undermining the Union's institutional and policy equilibrium over the long term.

Despite their differences, both recent developments in historical institutionalism and Greif and Laitin's theory of endogenous change make two central points: First, institutions may produce feedback effects that, over time, can lead to change in the institution itself. Second, these feedback effects may be positive, thus promoting a reinforcement of institutionalized cooperation, or they can be negative, undermining institutions and policies and possibly leading to their demise. Existing studies of the EU - drawing from theoretical sources including neofunctionalism, historical institutionalism and constructivism - have generally emphasized positive feedback, in which an initial integrative act can lead to functional spillover (Haas 1958), gaps in member-state control (Pierson 1996; Pollack 2003), long-term socialization of elites (Haas 1958; Checkel 2005a) and the negotiation of informal agreements that are subsequently codified over time (Farrell and Héritier 2005). The notion that EU institutions might have negative or self-undermining feedback effects has been explored less systematically, ${ }^{9}$ yet the Union's ongoing constitutional crisis and the long-term decline in public support for further integration suggest that negative feedback should be the focus of greater attention in future studies of institutional change. 
At the same time, however, both rational choice and other scholars should beware of the temptation to 'endogenize' all sources of change within a single theory or to attribute all change within the European Union to positive or negative feedback effects from the EU itself. As Immergut (2006: 6) aptly observes, 'Although exogenous change sounds like a fancy word for an ad hoc explanation, there are many interesting and systematic exogenous sources of change'. Indeed, while scholars should be attentive to possible feedback effects from European integration, it is both possible and likely that 'exogenous' factors, including political and economic changes on the world stage or critical elections within one or more member countries, have served and may continue to serve as the most important sources of change in the EU, and that the feedback effects of European integration may be rare or weak compared with other domestic and/or global sources of change.

\section{CONCLUSIONS}

There is an old expression to the effect that when you have a hammer, every problem looks like a nail. Critics of rational choice in EU studies have often argued that formal modelers in particular have approached the EU almost exclusively through the lens of their off-the-shelf theories, asking only narrow questions about those aspects of the EU that resemble, say, domestic legislatures or principal-agent relationships. There is, I have argued in this chapter, some truth to this claim: rational choice theorists have followed a positive heuristic that has pointed them toward the study of strategic interaction within institutional constraints and away from other questions such as socialization, deliberation and identity change.

Nevertheless, the picture presented in this chapter is broadly speaking a positive one, with respect to both rational choice analysis and the field of EU studies as a whole. With regard to the former, we have seen how, over the past several decades, students of the EU have adapted rational choice theories of politics with increasing sophistication to the myriad of specific questions we can ask about European integration and EU politics. Moreover, I have argued, the empirical record of these theories has been, on balance, positive and progressive, not pathological. While we do find some evidence of elaborate models subjected to cursory testing (or no testing at all), the broader picture is one in which scholars draw on rational choice theories (and other theories) to generate testable hypotheses about concrete political outcomes across a range of subject areas. Even in areas that have been considered to be outside the domain of application of rational choice, such as endogenous preference formation and change, rational choice theories have (alongside constructivists) contributed to the development of a sophisticated research program on EU socialization, as well as pioneering (alongside historical institutionalists) a revitalized discussion on the endogenous sources of change in the EU. Much remains to be done in these areas and the work reviewed here is in many cases suggestive rather than conclusive, but the claim that rational choice is 'ontologically blind' to such questions has not been borne out.

With regard to the health of the field overall, it is striking that the rational choice/constructivist divide in EU studies, which many scholars feared would descend into a metatheoretical dialogue of the deaf, has instead proven healthy to the field and to rationalist and constructivist theorists on both sides of the divide. To a very large extent, students of EU politics have taken a pragmatic and problem-driven approach: identifying an important problem, searching the existing literature (both rationalist and constructivist) for relevant insights and hypotheses and seeking to test those hypotheses through careful empirical analysis. This is the approach taken in much of the literature on public opinion, Europeanization, Eastern enlargement and socialization, and the same approach should be applicable to the full range of research questions in EU studies.

The case for rational choice, finally, can be made more forcefully. Thoughtful rational choice theorists over the past decade have argued that rational choice models should be most powerful within a certain domain, in which the stakes of individual decisions are considerable 
(making the calculation of expected utility worthwhile), the informational context is relatively rich (making calculation of expected utility possible) and the rules of the game are clearly and formally spelled out (Ferejohn and Satz 1996; Fiorina 1996). The European Union, whether we call it an international regime or a polity-in-the-making, has all of these characteristics, suggesting that EU politics is a promising forum for the elaboration and testing of rational choice theories even beyond the core areas explored in this chapter (Jupille 2004; Hix 2005). Put differently, across the full range of its activities, EU politics does indeed look like a nail and we as a discipline would do well to get some hammers.

\section{NOTES}

1. The author is grateful to Ben Rosamond and Knud Erik Jorgensen for comments on an earlier draft of this chapter.

2. Rational choice, as Elster (1986) notes, is both a normative and a positive theory. In normative terms, rational choice theory does not dictate the ends or aims to which individuals should strive, but it does 'tell us what we ought to do in order to achieve our aims as well as possible'. In contrast, rational choice as a positive theory adopts a particular set of assumptions about actors and about their social context and seeks to generate testable hypotheses about human behavior. Despite the significance of the normative aspect, I focus here on rational choice exclusively as a positive theory, inquiring whether rational choice theories have advanced our understanding of EU politics.

3. This is, of course, a severely compressed discussion of a theoretical approach whose basic tenets remain to some extent contested. For good discussions see e.g. Elster (1986), Ferejohn (1991) and Snidal (2002).

4 . The use of such models has been controversial, with critics accusing modelers of simply restating in simplified form basic insights already familiar to substantive experts in the field. However, as Snidal (2002: 77-8) has argued, formal models of collective action and international cooperation have produced non-intuitive or counter-intuitive findings that went largely against dominant views and generated specific predictions about both the obstacles and the solutions to collective action problems. For good discussions on the role of formal models in EU studies, see e.g. Hug (2003) and Pahre (2005).

5. For a useful collection of responses to Green and Shapiro's critique, see e.g. the essays collected in Friedman (1996b).

6. Foundational works in the RCI canon include Scharpf (1988), Garrett (1992), Tsebelis (1994) and Garrett and Tsebelis (1996). For useful reviews of institutionalism in EU studies, see e.g. Jupille and Caporaso (1999), Dowding (2000), Aspinwall and Schneider (2001) and Pollack (2004).

7. I am grateful to Andrew Moravcsik for suggesting the empirical fruitfulness of rational choice theory as a central focus of this chapter.

8. For an up-to-date study of the state of the art in the study of the Council, see Hayes-Renshaw and Wallace (2006); recent rationalist work on the Council that looks beyond the voting-power approach includes Mattila and Lane (2001), Mattila (2004) and the chapters in Thomson et al. (2006)

9. Lindberg and Scheingold's (1970) notion of 'spillback' is a notable, but underdeveloped and little-noted, exception.

\section{REFERENCES}

Albert, M. (2003) 'The voting power approach: measurement without theory', European Union Politics, 4(3): 351-66.

Alter, K.J. (2001) Establishing the Supremacy of European Law: The Making of an International Rule of Law in Europe. New York: Oxford University Press.

Aspinwall, M. and Schneider, G. (eds) (2001) The Rules of Integration: Institutionalist Approaches to the Study of Europe. New York: Manchester University Press.

Börzel, T.A. and Risse, T. (2000) 'When Europeanization hits home: Europeanization and domestic change', RSC Working Paper No. 2000/56, Robert Schuman Centre for Advanced Studies, European University Institute, Florence. Available online at: http://www.iue.it/RSCAS/WP-Texts/ 00_56.pdf, accessed 16 July 2006.

Büthe, T. (2006) 'Institutional persistence and change in international delegation', paper prepared for the Workshop on Delegating Sovereignty, Duke Law School, 3-4 March 2006.

Carrubba, C.J. and Volden, C. (2001) 'Explaining institutional change in the European Union: what determines the voting rule in the Council of Ministers?', European Union Politics, 2(1): 5-30.

Checkel, J.T. (ed.) (2005a) 'International institutions and socialization in Europe', special issue of International Organization, 59(4).

Checkel, J.T. (2005b) 'International institutions and socialization in Europe: introduction and framework', International Organization, 59(4): 801-26.

Checkel, J.T. and Moravcsik, A. (2001) 'A constructivist research programme in EU studies?', European Union Politics, 2(2): 219-49.

Christiansen, T., Jorgensen, K.E. and Wiener, A. (1999) 'The social construction of Europe', Journal of European Public Policy, 6(4): 528-44. 
Conant, L. (2002) Justice Contained: Law and Politics in the European Union. Ithaca, NY: Cornell University Press.

Crombez, C., Steunenberg, B. and Corbett, R. (2000) 'Understanding the EU legislative process: political scientists' and practitioners' perspectives', European Union Politics, 1(3): 363-81.

Dowding, K. (2000) 'Institutionalist research on the European Union: a critical review', European Union Politics, 1(1): 125-44.

Elster, J. (1986) 'Introduction', in J. Elster (ed.), Rational Choice. New York: New York University Press. pp. 1-33.

Epstein, D. and O'Halloran, S. (1999) Delegating Powers: A Transaction Cost Politics Approach to Policy Making under Separate Powers. New York: Cambridge University Press.

Farrell, H. and Héritier, A. (2005) 'A rationalistinstitutionalist explanation of endogenous regional integration', Journal of European Public Policy, 12(2): 273-90.

Fearon, J. and Wendt, A. (2002) 'Rationalism vs. constructivism: a skeptical view', in W. Carlnaes, B. Simmons and T. Risse (eds), Handbook of International Relations. New York: Sage. pp. 52-72.

Ferejohn, J. (1991) 'Rationality and interpretation: parliamentary elections in early Stuart England', in K.R. Monroe (ed.), The Economic Approach to Politics: A Critical Assessment of the Theory of Rational Action. New York: Harper Collins. pp. 279-305.

Ferejohn, J. and Satz, D. (1996) 'Unification, universalism, and rational choice theory', in J. Friedman (ed.), The Rational Choice Controversy. New Haven: Yale University Press.pp. 71-84.

Fiorina, M.P. (1996) 'Rational choice, empirical contributions and the scientific enterprise', in J. Friedman (ed.), The Rational Choice Controversy. New Haven: Yale University Press.pp. 85-94.

Franchino, F. (2002) 'Efficiency or credibility? Testing the two logics of delegation to the European Commission', Journal of European Public Policy, 9(5): 677-94.

Franchino, F. (2004) 'Delegating powers in the European Community', British Journal of Political Science, 34(2): 449-76.

Franchino, F. (2007) The Powers of the Union: Delegation in the EU. New York: Cambridge University Press, forthcoming.

Friedman, J. (1996a) 'Introduction: economic approaches to politics', in Friedman (ed.), The Rational Choice Controversy. New Haven: Yale University Press. pp. 1-23.

Friedman, J. (ed.) (1996b) The Rational Choice Controversy: Economic Models of Politics Reconsidered. New Haven: Yale University Press.
Gabel, M.J. (1998) Interests and Integration: Market Liberalization, Public Opinion, and European Integration. Ann Arbor: University of Michigan Press.

Garrett, G. (1992) 'International cooperation and institutional choice: the European Community's internal market', International Organization, 46(2): 533-60.

Garrett, G. (1995) 'The politics of legal integration in the European Union', International Organization, 49(1): 171-81.

Garrett, G. and Tsebelis, G. (1996) 'An institutional critique of intergovernmentalism', International Organization, 50(2): 269-99.

Garrett, G. and Weingast, B. (1993) 'Ideas, interests, and institutions: constructing the European Community's internal market', in J. Goldstein and R. Keohane (eds), Ideas and Foreign Policy. Ithaca: Cornell University Press. pp. 173-206.

Garrett, G., Kelemen, R.D. and Schulz, H. (1998) 'The European court of justice, national governments, and legal integration in the European Union', International Organization, 52(1): 149-176.

Garrett, G., Tsebelis, G. and Corbett, R. (2001) 'The EU legislative process: academics vs. practitioners round 2', European Union Politics, 2(3): 353-66.

Gerber, E.R. and Jackson, J.E. (1993) 'Endogenous preferences and the study of institutions', American Political Science Review, 87(3): 639-56.

Green, D.P. and Shapiro, I. (1994) Pathologies of Rational Choice Theory: A Critique of Applications in Political Science. New Haven: Yale University Press.

Greif, A. and Laitin, D.D. (2004) 'A theory of endogenous institutional change', American Political Science Review, 98(4): 633-52.

Haas, E.B. (1958) The Uniting of Europe: Political, Social and Economical Forces 1950-1957. London: Stevens \& Sons Limited.

Haas, E.B. (2001) 'Does constructivism subsume neo-functionalism?', in T. Christiansen, K.E. Jorgensen and A. Wiener (eds), The Social Construction of Europe. London: Sage Publications. pp. 22-31.

Hall, P.A. and Thelen, K. (2006) 'Varieties of capitalism and institutional change', APSA European Politics \& Society: Newsletter of the European Politics and Society Section of the American Political Science Association, 5(1): 1, 3-4. Available online at: http://www.apsanet.org/ ep/newsletter.html, accessed 21 August 2006.

Hawkins, D., Lake, D.A., Nielsen, D. and Tierney, M.J. (eds) (2006) Delegation and Agency in International Organizations. New York: Cambridge University Press. 
Hayes-Renshaw, F. and Wallace, H. (2006) The Council of Ministers, 2nd edn. London: Palgrave.

Helfer, L.R. (2006) 'Theories of change in international organizations', Paper presented at the Conference on 'Delegating Sovereignty: Constitutional and Political Perspectives', Duke University, 3-4 March 2006. Available online at: http://www.law.duke. edu/publiclaw/workshop/papers.html, accessed 21 August 2006.

Hix, S. (2001) 'Legislative behaviour and party competition in EP: an application of nominate to the EU', Journal of Common Market Studies, 39(4): 663-88.

Hix, S. (2005) The Political System of the European Union, 2nd edn. New York: Palgrave.

Hix, S., Noury, A. and Roland, G. (2002) 'A “normal” parliament? Party cohesion and competition in the European Parliament, 1979-2001', EPRG Working Paper, No 9. Available online at: http://www.lse. ac.uk/Depts/eprg/working-papers.htm, accessed 21 August 2006.

Hoffmann, S. (1966) 'Obstinate or obsolete? The fate of the nation-state and the case of western Europe', Doedalus, 95(3): 862-915.

Hooghe, L. and Marks, G. (2004) 'Does identity or economic rationality drive public opinion on European integration?', PS: Political Science and Politics, 37(3): 415-20.

Huber, J.D. and Shipan, C.R. (2003) Deliberate Discretion: The Institutional Foundations of Bureaucratic Autonomy. New York: Cambridge University Press.

Hug, S. (2003) 'The state that wasn't there: the future of EU institutions and formal models', European Union Politics, 4(1): 121-34.

Immergut, E. (2006) 'From constraints to change', APSA European Politics \& Society: Newsletter of the European Politics and Society Section of the American Political Science Association, 5(2): 4-6.

Jacoby, W. (2004) The Enlargement of the European Union: Ordering from the Menu in Central Europe. New York: Cambridge University Press.

Johnston, A.I. (2005) 'Conclusions and extensions: toward mid-range theorizing and beyond Europe', International Organization, 59(4): 1013-44.

Jupille, J. (2004) Procedural Politics: Issues, Influence, and Institutional Choice in the European Union. New York: Cambridge University Press.

Jupille, J. (2005) 'Knowing Europe: metatheory and methodology in European Union studies', in M. Cini and A.K. Bourne (eds), Palgrave Advances in European Union Studies. New York: Palgrave. pp. 209-32.

Jupille, J. and Caporaso, J.A. (1999) 'Institutionalism and the European Union: beyond international relations and comparative politics', Annual Review of Political Science, 2: 429-44.

Jupille, J. and Snidal, D.A. (2005) 'The choice of international institutions: cooperation, alternatives and strategies', unpublished paper.

Jupille, J., Caporaso, J.A. and Checkel, J.T. (2003) 'Integrating institutions: rationalism, constructivism, and the study of the European Union', Comparative Political Studies, 36(1-2): 7-40.

Katzenstein, P.J., Keohane, R.O. and Krasner, S.D. (1998) 'International Organization and the study of world politics', International Organization, 52(4): 645-85.

Kelley, J. (2004) 'International actors on the domestic scene: membership conditionality and socialization by international institutions', International Organization, 58(2): 425-58.

Kilroy, B. (1999) 'Integration through law: ECJ and governments in the $\mathrm{EU}, \mathrm{PhD}$ dissertation, UCLA.

Koremenos, B., Lipson, C. and Snidal, D. (eds) (2003) The Rational Design of International Institutions. New York: Cambridge University Press.

Kreppel, A. (1999) 'The European Parliament's influence over EU policy outcomes', Journal of Common Market Studies, 37(3): 521-38.

Kreppel, A. (2001) The European Parliament and Supranational Party System: A Study in Institutional Development. New York: Cambridge University Press.

Lakatos, I. (1970) 'Falsification and the methodology of scientific research programs', in I. Lakatos and A. Musgrave (eds), Criticism and the Growth of Knowledge. New York: Cambridge University Press. pp. 91-196.

Lewis, J. (2005) 'The Janus face of Brussels: socialization and everyday decision making in the European Union', International Organization, 59(4): 937-71.

Lindberg, L.N. and Scheingold, S.A. (1970) Europe's Would-Be Polity: Patterns of Change in the European Community. Englewood Cliffs, NJ: Prentice Hall.

Mattila, M. (2004) 'Contested decisions - empirical analysis of voting in the EU council of ministers', European Journal of Political Research, 43(1): 29-50.

Mattila, M. and Lane, J.-E. (2001) 'Why unanimity in the Council?', European Union Politics, 2(1): 31-52.

Mattli, W. and Slaughter, A.-M. (1995) 'Law and politics in the European Union: a reply to Garrett', International Organization, 49(1): 183-90.

Mattli, W. and Slaughter, A.-M. (1998) 'Revisiting the European Court of Justice', International Organization, 52(1): 177-209. 
Moravcsik, A. (1998) The Choice for Europe: Social Purpose and State Power from Messina to Maastricht. Ithaca, NY: Cornell University Press.

Moravcsik, A. (1999) 'Is something rotten in the state of Denmark? Constructivism and European integration', Journal of European Public Policy, 6(4): 669-81.

Moser, P., Schneider, G. and Kirchgässner, G. (eds) (2000) Decision Rules in the European Union: A Rational Choice Perspective. New York: St. Martin's Press.

North, D. (1990) Institutions, Institutional Change and Economic Performance. New York: Cambridge University Press.

Pahre, R. (2005) 'Formal theory and case-study methods in EU studies', European Union Politics, 6(1): 113-45.

Pierson, P. (1996) 'The path to European integration: a historical institutionalist analysis', Comparative Political Studies, 29(2): 123-63.

Pierson, P. (2000) 'Increasing returns, path dependence, and the study of politics', American Political Science Review, 94(2): 251-67.

Pierson, P. (2004) Politics in Time: History, Institutions and Social Analysis. Princeton: Princeton University Press.

Pollack, M.A. (1997) 'Delegation, agency, and agenda-setting in the European Community', International Organization, 51(1): 99-134.

Pollack, M.A. (2003) The Engines of European Integration: Delegation, Agency, and Agenda Setting in the EU. Oxford: Oxford University Press.

Pollack, M.A. (2004) 'The new institutionalisms and European integration', in A. Wiener and T. Diez (eds), European Integration Theory. New York: Oxford University Press. pp. 137-56.

Risse, T. (2000) “"Let's argue!” Communicative action and world politics', International Organization, 54(1): 1-39.

Risse, T. (2005) 'Neo-functionalism, European identity, and the puzzles of European integration', Journal of European Public Policy, 12(2): 291-309.

Sandholtz, W. (1996) 'Membership matters: limits of the functional approach to European institutions', Journal of Common Market Studies, 34(3): 403-29.

Scharpf, F.W. (1988) 'The joint-decision trap: lessons from German federalism and European integration', Public Administration, 66(3), 239-78.

Schimmelfennig, F. (2005) 'Strategic calculation and international socialization: membership incentives, party constellations, and sustained compliance in central and eastern Europe', International Organization, 59(4): 827-60.
Schimmelfennig, F. and Sedelmeier, U. (2002) 'Theorising EU enlargement: research focus, hypotheses, and the state of research', Journal of European Public Policy, 9(4): 500-28.

Schimmelfennig, F. and Sedelmeier, U. (eds) (2005a) The Europeanization of Central and Eastern Europe. Ithaca: Cornell University Press.

Schimmelfennig, F. and Sedelmeier, U. (2005b) 'Introduction: conceptualizing then Europeanization of central and eastern Europe', in F. Schimmelfennig and U. Sedelmeier (eds), The Europeanization of Central and Eastern Europe. Ithaca: Cornell University Press. pp. 1-28.

Schimmelfennig, F., and Sedelmeier, U. (2005c) 'Conclusions: the impact of the EU on the accession countries', in F. Schimmelfennig and U. Sedelmeier (eds), The Europeanization of Central and Eastern Europe. Ithaca: Cornell University Press. pp. 210-28.

Scully, R.M. (2005) 'Rational institutionalism and liberal intergovernmentalism', in M. Cini and A.K. Bourne (eds), Palgrave Advances in European Union Studies. New York: Routledge. pp. 19-34.

Snidal, D. (2002) 'Rational choice and international relations', in W. Carlnaes, B. Simmons and T. Risse (eds), Handbook of International Relations. New York: Sage. pp. 73-94.

Stone Sweet, A. and Brunell, T.L. (1998) 'Constructing a supranational constitution: dispute resolution and governance in the European Community', American Political Science Review, 92(1): 63-81.

Stone Sweet, A. and Caporaso, J.A. (1998) 'From free trade to dupranational polity: the European Court and integration', in W. Sandholtz and A. Stone Sweet (eds), European Integration and Supranational Governance. New York: Oxford University Press. pp. 92-133.

Streeck, W. and Thelen, K. (2005) 'Introduction: institutional change in advanced political economies', in W. Streeck and K. Thelen (eds), Beyond Continuity: Institutional Change in Advanced Political Economies. New York: Oxford University Press. pp. 1-39.

Tallberg, J. (2000) 'The anatomy of autonomy: an institutional account of variation in supranational influence, Journal of Common Market Studies, 38(5): 843-64.

Tallberg, J. (2003) European Governance and Supranational Institutions: Making States Comply. London: Routledge.

Thomson, R., Stokman, F.N., König, T. and Achen, C. (eds) (2006) The European Union Decides: The Empirical Relevance of Policy-Making Models. 
New York: Cambridge University Press, forthcoming.

Tsebelis, G. (1994) 'The power of the European Parliament as a conditional agenda setter', American Political Science Review, 88(1): 129-42.

Tsebelis, G. (1997) 'Maastricht and the democratic deficit', Aussenwirtschaft, 52(1): 29-56.

Tsebelis, G. (2002) Veto Players: How Political Institutions Work. Princeton: Princeton University Press.

Tsebelis, G., Jensen, C.B., Kalandrakis, A. and Kreppel, A. (2001) 'Legislative procedures in the
European Union', British Journal of Political Science, 31(4): 573-99.

Vachudova, M.A. (2005) Europe Undivided: Democracy, Leverage, and Integration after Communism. New York: Oxford University Press. Wendt, A. (1999) Social Theory of International Politics. New York: Cambridge University Press.

Zürn, M. and Checkel, J.T. (2005) 'Getting socialized to build bridges: constructivism and rationalism, Europe and the nation-state', International Organization, 59(4): 1045-79. 
